\title{
Testje doen?
}
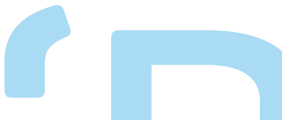

'Dokter, kunt u mijn bloed laten testen? Kunt u mijn hart nakijken? Kunt u eens kijken naar dit stukje huid? Ik wil graag weten of ik de ... ziekte heb.'

Huisartsen vragen vaak aanvullende diagnostiek aan. Om een ziekte uit te sluiten of aan te tonen, bedenktijd te kopen, de patiënt gerust te stellen, niets te willen missen, comorbiditeit te vangen in visrijk water, of om het consult te kunnen afronden. En dan hopen we altijd op een dichotome uitslag, ja of nee, schijnbaar alles laten afhangend van de test.

$\mathrm{Na}$ het lezen van wat H\&W deze maand publiceert twijfel ik over de effectiviteit van deze strategie. De werkelijkheid is veel complexer. De D-dimeertest is eigenlijk alleen nuttig als we deze aanvragen ná het toepassen van de beslisregel. Een spirometrie goed uitvoeren blijft lastig en huisartsen en longartsen interpreteren de uitslag nogal verschillend. Een ontstekingsfactormeting (FeNO) bij astma lijkt alleen zin te hebben bij een subgroep patiënten. Routinematig ecg's doen bij diabetespatiënten gaat de cardiovasculaire zorg niet verbeteren. En om te weten hoe ik een COVID-19 PCR-test moet duiden, moet ik dagelijks kijken naar de golfhoogte van de epidemie.

Is met zo'n test de patiënt eigenlijk wel

geholpen? Is de ziektelast verminderd of de hulpvraag beantwoord? Twijfelachtig. Wat als ik al dat aanvullend testen terzijde schuif? Als ik persoons- en contextgerichte zorg vormgeef door als uitgangspunt te nemen wat ik hoor, zie en voel in het contact met de patiënt? Als ik nu eens kijk naar wat ik kan dóen, in plaats van wat ik kan meten? COPD-onderzoekers spreken over 'Treatable Traits': relevante kenmerken van de aandoening die in de spreekkamer goed in beeld te brengen zijn en waarvoor een gerichte aanpak bestaat. Bij COPD zijn er 151 combinaties van 'Treatable Traits', dus per patiënt en ziekte verschillend. Het zou wel eens met de persoon en context te maken kunnen hebben... Is dat niet onze corebusiness?

Terug naar mijn spreekuur: 'Ja, prima om test $\mathrm{X}, \mathrm{Y}$ of $\mathrm{Z}$ te doen. Maar wat de uitslag ook is, laten we eens naar uw klachten en vragen kijken, wat we daar nu mee kunnen doen en wat bij u past.'

Persoonsgerichte huisartsenzorg!?

Ivo Smeele, hoofdredacteur 